\title{
Making Comparative Constitutional Law Work: Naz Foundation and the Constitution of India
}

\author{
By Priya Urs*
}

The recent decision of the High Court of Delhi in Naz Foundation v. N.C.T. of Delhi and Others, in which the Court declared the unconstitutionality of a colonial legislation to the extent that it penalizes consensual sexual intercourse by adult homosexual individuals in private, is currently in appeal before the Supreme Court of India. The judgment is considerably inventive, creating a stir in public debate about the fundamental rights to dignity, privacy and others, which continue to remain largely nebulous in Indian jurisprudence. What makes the decision most interesting, and contentious, is its heavy reliance on foreign sources - the judgments of foreign legal systems, as well as international texts. To what extent do external sources contribute, if at all, to the legitimacy of a judicial outcome? This question cannot go unanswered in the context of an issue so deeply embedded in societal perceptions of morality, and finds special relevance in India, and its body of elaborate constitutional jurisprudence today. In this paper, the author seeks to address some of the concerns regarding the use of comparative constitutional law in judicial decision-making, particularly in a democracy like India, in an endeavour to justify its use in Naz Foundation.

\section{A. Introduction}

Having had the privilege of witnessing the courtroom proceedings in the State's appeal to the Supreme Court of India from the hotly debated decision of the High Court of Delhi in the landmark (as it is frequently termed) case, Naz Foundation v. Government of N.C.T. of Delhi and Others, ${ }^{1}$ I will in this article offer an understanding of why Naz Foundation is indeed a landmark judgment in Indian jurisprudence. First, and most obviously, is the Court's recognition and treatment of the rights of homosexual people, not just to engage in consensual sexual intercourse in private, but also to a life of dignity free from State discrimination and intrusion. Secondly, from a jurisprudential perspective, is the novel approach it seems to have adopted in justifying the unconstitutionality of what many people today consider to be an archaic, reprehensible law punishing sodomy - Section 377 of the Indian Penal Code, 1860.

A writ petition in the form of a Public Interest Litigation was filed before the High Court of Delhi by Naz Foundation, a non-governmental organization, challenging the constitutional

* The author is currently a V Year student of the B.A., LL.B. (Honours) Programme at the National Law School of India University, Bangalore, India, and can be contacted at priyaurs33@gmail.com. The author would like to thank Professor Philipp Dann and Michael Riegner for their valuable comments on this article.

1 Naz Foundation v. Government of N.C.T. of Delhi and Others 160 (2009) D.L.T. 277. 
validity of Section 377 to the extent that the 'unnatural offences' it penalizes include consensual sexual acts by adults in private, resulting in the violation of several of the Fundamental Rights protected by the Indian Constitution, including the rights to equality, privacy, and dignity. Bursting through the seams of legal language and constitutional interpretation, the petition soon became the subject of public debate, anticipated by many as an opportunity to establish largely non-existent rights for homosexual individuals in India, and by others as disrupting the traditional values they perceive to be essential to the social fabric of Indian society.

Perhaps the most striking feature of the High Court's decision in Naz Foundation is its use of changed constitutional interpretations to justify its view, rather than the simpler task of re-interpreting the provisions of Section 377 in a contemporary context, far removed from the Victorian era in which it was envisaged. Section 377 states:

'Whoever voluntarily has carnal intercourse against the order of nature with any man, woman or animal, shall be punished with imprisonment for life, or with imprisonment of either description for a term which may extend to ten years, and shall also be liable to fine. Explanation. - Penetration is sufficient to constitute the carnal intercourse necessary to the offence described in this section.'

In declaring this provision unconstitutional, the High Court seems to have risked losing the legitimacy of its decision, using a yet uncertain jurisprudence on rights like dignity and privacy - which find no explicit protection in the Constitution - to justify its stance, instead of clarifying, using a more traditional legalistic approach, the kinds of acts that Section 377 actually penalises. In this way, the Court could have safely excluded sexual intercourse between consenting adult homosexuals as falling outside the scope of this provision, without drawing too much criticism. Even by choosing a constitutional approach, it would have been relatively easier for the Court to have struck down 'order of nature' as violating the right to equality in Article 14 of the Constitution, owing to its arbitrariness. ${ }^{2}$

Instead, the Court chose to embark on a considerably longer journey, delving into various provisions of the Indian Constitution, to validate its stand. The use of comparative constitutional law is more than evident in its discussion of the variety of issues that fell for consideration. Before the Supreme Court, in fact, the State vehemently argued that the High Court's reliance on constitutions and cases belonging to foreign jurisdictions was entirely unacceptable.

The High Court nevertheless proceeded to read 'sexual orientation' into Article 15 with substantial support from the South African Constitution and the Supreme Court of Canada, validate the Article 14 challenge using the U.S. Supreme Court's decision striking down

2 This alternative has been proposed by Vikram Raghavan in his critique of the Delhi High Court's judgment, available at http://lawandotherthings.blogspot.in/2009/07/navigating-noteworthy-and-nebulous-in.html. For an understanding of the Indian Judiciary's interpretation of the constitutional right to equality and the requirement of non-arbitrariness, see M. P. Jain, Indian Constitutional Law, New Delhi, 2007, pp. 856-7. 
Texas' sodomy law in Lawrence v. Texas,${ }^{3}$ reject the State's 'popular morality' argument with the European Court of Human Rights' decision in Dudgeon v. United Kingdom, ${ }^{4}$ and use the Human Rights Committee's decision quashing Tasmania's sodomy law for violating the ICCPR to include the right to privacy in Article 21. It did not stop here. The Court went on to emphasize global trends towards the decriminalization of homosexual activity in the United Kingdom, New Zealand, Fiji, Hong Kong and Nepal.

Each of these references provides ample scope for more focused discussion about the use of comparative constitutional methods in Naz Foundation, whether substantively through its human rights emphasis, or procedurally, through its uninhibited use of the American strict scrutiny test, and the comparative sources that have been referred to in the context of each issue. I have, however, refrained from selecting a single issue for discussion and will instead, in this article, attempt to provide an understanding of why the use of comparative constitutional law in Naz Foundation is considerably new and different, and, in this way, illustrate how it lends greater legitimacy to the Court's decision based on this innovative methodology.

\section{B. The Legitimacy of Constitutional Borrowing in Judicial Decision-Making}

To what extent do international texts and foreign judgments aid in legitimizing judicial pronouncements in a particular jurisdiction? Addressing this question is crucial to appreciate the use of a comparative approach in Naz Foundation, particularly in light of convincing arguments to the contrary. Scalia, J.'s powerful dissent in Lawrence v. Texas, for instance, accurately captures his decided rejection of foreign sources - or 'dangerous dicta' - which allow judges to legitimize outcomes that would otherwise be impermissible. This view must be understood in the context of democracy, which, by its very nature, tends to prioritise the historical and social experiences of a particular context. ${ }^{5}$ The implications of the use of comparative constitutional law in light of the democracy question are vast, raising concerns about the legitimacy of constitutional borrowing among societies which accord great importance to their democratic commitments. I will limit myself to an analysis of the implications of the use of foreign sources in the context of Naz Foundation for a democratic country like India in Part $\mathrm{D}$ of this article.

Coming now to the crucial question at hand: what is the appeal of comparative constitutional law? Simply stated, comparative constitutional law affords one State the opportunity to improve its legal system through an understanding of the rules and framework of another. ${ }^{6}$ This approach is used with increasing frequency, not only during constitution-making

3 Lawrence v. Texas 539 U.S. 558 (2003).

4 Dudgeon v. United Kingdom, Appl. No. 7525/76, Council of Europe: European Court of Human Rights, 22 October 1981, available at: http://www.unhcr.org/refworld/docid/47fdfaf7 d.html.

5 Supra note 3, at 577; A. L. Parrish, Storm in a Teacup: The U.S. Supreme Court's Use of Foreign Law, University of Illinois Law Review 637 (2007), p. 653.

6 A. Watson, Comparative Law and Legal Change, The Cambridge Law Journal 37(2) (1978), pp. 313, 317. 
processes, but in the course of judicial interpretation as well. I will now proceed to discuss why Naz Foundation does precisely this, in the most legitimate way possible.

The most important aspect of the comparative approach adopted by the High Court, and perhaps the most compelling in support of its decision, is its reliance on foreign materials not merely for the purpose of interpreting the Indian Constitution, but to portray the convergence of a variety of constitutions the world over on an issue that is deeply rooted in particularistic notions of morality. ${ }^{7}$ An interesting empirical study of the world's constitutions by David Law and Mila Versteeg illustrates a trend towards the inclusion of a greater number of rights in constitutions today, of which the number of rights they have in common is also increasing. ${ }^{8}$ This conclusion is hardly surprising considering international developments that recognize various species of universal human rights. The High Court seems to have been acutely aware of India's obligations in placing its Constitution in this international context. In fact, $\mathrm{Naz}$ Foundation is often regarded as a 'test' case for human rights law in India. ${ }^{9}$ Consequently, the Court has used this universalist approach to portray its decision as part of a larger global initiative for the protection of human rights, rather than viewing the Constitution narrowly, as 'a symbol of the legal state', seeming to undermining the value of democracy. ${ }^{10}$

The universalism embraced by the High Court is, quite noticeably, opposed to notions of cultural relativism (or cultural nationalism), ${ }^{11}$ a species of the broader notion of self-determination, which rejects all comparative materials owing to the fact that they do not emanate from India's cultural context. ${ }^{12}$ This seems to be a manifestation of the more sweeping demand for democratic legitimacy. A related argument is that reliance on foreign sources that have come into existence after the Indian Constitution came into force could have had no influence on its drafting and should not be used to interpret its provisions. ${ }^{13}$

In response to these criticisms, many of which raise valid concerns about the legitimacy of comparative constitutional law in judicial decision-making, I will defend its use in $\mathrm{Naz}$ Foundation in particular, rather than undertaking the formidable task of defending comparative constitutional law in its entirety.

7 S. Choudhry, How To Do Comparative Constitutional Law in India: Naz Foundation, Same Sex Rights, and Dialogical Interpretation (2010), p. 14, available at http://papers.ssrn.com/sol3/papers.cfm?abstract_id $=1673378$.

8 D. Law and M. Versteeg, The Evolution and Ideology of Global Constitutionalism, The California Law Review 99 (2010), pp. 1163, 1164.

9 R. Wintemute, Same-Sex Love and Indian Penal Code § 377: An Important Human Rights Issue for India, NUJS Law Review 4 (2011), pp. 31, 39.

10 Pavle Nikolic has discussed the nature and role of a constitution in democratic societies. See P. Nikolic, Constitutional Review of Laws by Constitutional Courts and Democracy: Problem of Legitimacy, in: M.P. Singh (ed.), Comparative Constitutional Law, Lucknow 2011, pp. 33-37.

11 Choudhry, note 7, p. 25.

12 For a more comprehensive discussion of the arguments of cultural relativists, see Choudhry, note 7, pp. 25-6.

13 C. Saunders, The Use and Misuse of Comparative Constitutional Law Indiana Journal of Global Legal Studies 13(1) (2006), pp. 37, 49. 


\section{Defending the Comparative Methodology in Naz Foundation}

The Delhi High Court has, in using an inclusive comparative style, invited minimal disapproval from cultural relativists (and others who reject comparative constitutional law) by taking into account a number of legal systems in which laws against sodomy have been abolished, paving the way for greater human rights protection. By its artful convergence of varied and geographically dispersed jurisdictions, Naz Foundation immunizes itself from concerns about 'cherry-picking' ${ }^{14}$ and encourages reciprocity of borrowing among nations. This is a huge step forward, considering existing views ${ }^{15}$ of comparative law as involving one-way transfers only. In fact, Naz Foundation rejects altogether the outdated assumption in comparative constitutional law that only certain western legal systems are ideal for borrowing (since only civilized societies were assumed to have legal systems), ${ }^{16}$ choosing instead to weigh various foreign sources equally. This trend seems to suggest that normative decisions based on indeterminate notions of ideas like morality or justice are increasingly arrived at through international dialogue, rather than leaving societies to answer them independent of one another.

What makes the Court's approach in Naz Foundation most compelling, then, is the manner in which it has nullified stale arguments that gay rights are a western construct with no place in 'traditional' societies. Legitimising its interpretation, the Court has weaved together its carefully selected sources to reveal a greater degree of tolerance in countries closer to home, displaying widespread respect for certain core values. ${ }^{17}$ Its treatment of gay rights has been satisfactorily reinforced by its reflection of a growing global consensus among a diversity of nations.

This discussion brings us to the next justification for the use of comparative methodology in Naz Foundation. Advocates in favour of comparative constitutional law often highlight the utility it serves by encouraging and initiating processes of constitutional self-reflection. ${ }^{18}$ This is beneficial in two ways. First, it requires a judiciary that disagrees with an internationally accepted position of law to meet a higher standard in support of its dissent. Had the Court justified the constitutionality of Section 377, it would have been accountable to a greater extent

14 M. Khosla, Inclusive Constitutional Comparison: Reflections on India's Sodomy Decision, American Journal of Comparative Law (2011), pp. 23-4, available at http://papers.ssrn.com/sol3/papers.cfm? abstract_id $=1690567$.

15 Brenda Cossman, for example, argues that Canadian jurisprudence on same-sex marriages has been imported very little by other States. See B. Cossman, Migrating Marriages and Comparative Constitutionalism, in: S. Choudhry (ed.), The Migration of Constitutional Ideas, Cambridge 2008, pp. 209, 211.

16 Khosla, note 14, p. 11; C.F. W. Menski, Comparative Law in a Global Context: The Legal Systems of Asia and Africa, Cambridge 2006, p. 46.

17 This is a part of the increasing acceptance of homosexual communities in various parts of Asia. See $J$. Thottam, Why Asia's Gays are Starting to Win Acceptance, Time (24 August, 2009), available at http://www.time.com/time/printout/0,8816,1916097,00.html; Supra note 14, pp. 23-4.

18 This concept has been discussed in greater length by Sujit Choudhry. See Choudhry, note 7, p. 16. 
for its deviation from contrary trends in other legal systems. This provides some comfort in a world where nations are often at odds with internationally recognized rights. Secondly, from a more practical viewpoint, the use of comparative constitutional law in judicial decisionmaking is a convenient catalyst for legal change, since borrowing is considered the "cheapest and most efficient' ${ }^{19}$ way to change the law. This is particularly important in a country in which the Legislature has been slow to update obsolete laws and implement international commitments in a number of crucial areas.

Specifically in the context of Section 377, the second purpose served by constitutional self-critique is considerable. The High Court's repeated referenced to the development of English laws relating to sodomy, ${ }^{20}$ and the Wolfenden Committee Report recommending their abolition, ${ }^{21}$ lends greater legitimacy to the use of international materials, and seems to have played a critical role in supporting its reconsideration. This would not have been possible had the Court relied solely on the Indian Constitution.

\section{Justifying the Use of Foreign Sources with the Indian Constitution}

An evaluation of the use of comparative constitutional law in Naz Foundation would be incomplete without addressing whether its use of foreign judgments, international conventions and other cross-border initiatives are adequately supported by the Constitution of India itself. The use of untouchability as an analogy for sexual orientation, for instance, fulfils this expectation, inviting greater acceptance of comparative materials by contextualizing them in India's socio-legal history. The logic of the Court seems to have been that since the Indian Constitution has denounced the practice of untouchability, we must condemn discrimination on the basis of sexual orientation for exactly the same reasons. It is interesting to notice that, while the judgment does not cite a single Indian source that recognizes sexual orientation as a basis for discrimination, the mood of social inclusiveness during the Constituent Assembly debates has been used to fit this comfortably into India's constitutional culture, condemning a form of discrimination that was not discussed by the constitution-makers. ${ }^{22}$ This shows that the decision is, to an appreciable extent, respectful of cultural relativists' concerns while remaining loyal to the Constitution. Furthermore, in protecting Articles 14, 15, 19 and 21, the Court has stressed that in no circumstances can constitutional morality be overshadowed by public morality. ${ }^{23}$ The manner in which the Court has incorporated these ideas, despite its heavy universalistic bent, brings in a degree of balance in affording constitutional protection to unanticipated and neglected rights.

19 Watson, note 6, p. 326.

20 Section 1 of the Sexual Offences Act, 1967 decriminalised consensual sexual relations between adult men in the United Kingdom. See I. Loveland, Constitutional Law, Administrative Law, and Human Rights - A Critical Introduction, London, 2006, p. 637.

21 Supra note 1, p. 82.

22 Supra note 1, pp. 130-1.

23 Supra note 1, p. 86. 
Consequently, while Naz Foundation is often considered a product of comparative constitutional law, this characterization seems slightly inaccurate. What makes this judgment commendable, giving it greater legitimacy than predecessors that have used comparable techniques, is the manner in which foreign and international sources have been utilized, not as uninvited impositions that dilute constitutionalism in India, but as instruments to illuminate and extend to homosexual communities the rights that have gone unnoticed - privacy, ${ }^{24}$ dignity, ${ }^{25}$ and the right against discrimination on the basis of sexual orientation - but have always been within our Constitution, waiting to be unearthed.

This poses the larger question of whether the Constitution of India should be, and, in fact, is, a living document that allows us to update our changing reflections on issues that extend far beyond legal jurisprudence, and into realms of morality. Our collective perception on issues such as the private lives of homosexual individuals is in a perpetual state of flux, and requires constant revision, either by Parliament in enacting and repealing laws, or by the courts in interpreting them. The Delhi High Court has recognized the importance of this flexibility, despite the permanence that a constitutional document is expected to have. It is yet to be seen whether the Supreme Court, in the exercise of its appellate jurisdiction, will recognize the Constitution's potential to confer rights not contemplated at the time of drafting India's elaborate Constitution upon a class of people that had largely been ignored. In the words of Professor R. H. Graveson: 'People are bound together by common problems and by the desire to share in the achievements of other nations. ${ }^{26}$ This is precisely what comparative constitutional law should aim to achieve, and this is the philosophy that Naz Foundation embraces.

24 For a detailed discussion of the expansion of Article 21, see B. Errabbi, The Right to Personal Liberty in India: "Gopalan" Revisited with a Difference, in: M. P. Jain (ed.), Comparative Constitutional Law Lucknow 2011, p. 533.

25 For a detailed discussion of the concept of dignity, see G. Mishra, The Concept of Human Dignity and the Constitution of India, in: M. P. Jain (ed.), Comparative Constitutional Law, Lucknow 2011, p. 627.

26 R. H. Graveson, Philosophy and Function in Comparative Law, The International and Comparative Law Quarterly 7(4) (1958), pp. 649, 656. 